(c) American Dairy Science Association, 2006.

\title{
Molecular Characterization of Peptides Released from $\beta$-Lactoglobulin and $\alpha$-Lactalbumin via Cardosins A and B
}

\author{
R. M. Barros and F. X. Malcata ${ }^{1}$ \\ Escola Superior de Biotecnologia, Universidade Católica Portuguesa, \\ Rua Dr. António Bernardino de Almeida, P-4200-072 Porto, Portugal
}

\begin{abstract}
Crude mixtures of aspartic proteases from flowers of the plant Cynara cardunculus have been studied frequently, as have activities of such enzymes (in pure form) on caseins from bovine, ovine, and caprine sources. This research study addressed pure bovine whey protein as substrates; that is, $\alpha$-lactalbumin $(\alpha$ LA) and $\beta$-lactoglobulin ( $\alpha$-LG), submitted to hydrolysis by 1 of 2 aspartic proteases (cardosins A and B), previously extracted and purified from $C$. cardunculus. Samples collected, following incubation at $55^{\circ} \mathrm{C}$ and $\mathrm{pH}$ 5.2 , were assayed by fast protein liquid chromatography, reversed phase-high performance liquid chromatography, and tricine-sodium dodecyl sulfate polyacrylamide gel electrophoresis; the major peptides released were then collected and sequenced by Edman degradation. Cardosin B and, to a lesser degree, cardosin A showed proteolytic activity toward $\alpha$-LA, but the hydrolyzates produced were characterized by distinct peptide profiles. Cardosin B possesses a broad specificity, and produces several hydrophobic peptides (at least 5, with molecular mass in the range 2 to $8 \mathrm{kDa}$ ) in the early stages, which eventually become more hydrophilic (with molecular mass below $2 \mathrm{kDa}$ ) at later stages of hydrolysis. Cardosin A was found to cleave $\alpha$-LA at the peptide bonds Phe28-Arg29, Gly54-Tyr55, Ala59-Ile60, Leu71-Phe72, and Leu105-Thr106, whereas cardosin B cleaved Ala19-Glu20, Phe28-Arg29, Glu30-Leu31, Tyr37-Gly38, Trp45-Val46, Phe50-His51, Ala59-Ile60, Ser66-Thr67, Leu71-Phe72, Phe72-Gln73, Gln73-Ile74, Ile78-Trp79, Leu115-Asp116, and Leu124-Ala125. Conversely, cardosins $\mathrm{A}$ and $\mathrm{B}$ are apparently not active on $\beta$-LG.
\end{abstract}

Key words: whey protein, hydrolysis, aspartic protease, Cynara cardunculus

\section{INTRODUCTION}

The flowers of the wild thistle, Cynara cardunculus, contain 2 aspartic proteases (EC 3.4.23), tentatively

Received July 13, 2005

Accepted September 5, 2005.

${ }^{1}$ Corresponding author: fxmalcata@esb.ucp.pt named cardosin $\mathrm{A}$, the most abundant $(\sim 75 \%)$, and cardosin B (Faro, 1991; Veríssimo et al., 1995; RamalhoSantos et al., 1997; Barros et al., 2001). Crude aqueous extracts of $C$. cardunculus play an important role in traditional cheese making throughout the Iberian Peninsula. Cardosins A and B have been isolated and purified (Faro, 1991; Faro et al., 1995; Veríssimo et al., 1996; Barros et al., 2001) and they share several physicochemical characteristics. Both are inhibited by pepstatin, have an acid $\mathrm{pH}$ optimum, and exhibit a preference for peptide bonds between hydrophobic amino acid residues. Furthermore, cardosins A and B are heterodimeric, being composed of 2 dissimilar polypeptide subunits, with molecular masses of 31 and $15 \mathrm{kDa}$, and 34 and $14 \mathrm{kDa}$, respectively. Cardosin $\mathrm{A}$ is thought (Veríssimo et al., 1995; Pires, 1998) to be similar to chymosin, and cardosin B to pepsin in terms of specificity and activity. In the particular case of caseins, cardosin B is more proteolytic than cardosin A (Esteves et al., 1995; Pires, 1998, Silva and Malcata, 2000).

Whey proteins are not in general easily broken down by proteases (e.g., pepsin and trypsin); this factor accounts for their tendency to eventually cause allergies upon ingestion (Schmidt et al., 1995). $\beta$-Lactoglobulin consists of 162 amino acid residues, and folds upon itself in a specific way due to the presence of 2 disulfide bonds; they create a strong hydrophobic core, and consequently hamper access of enzymes to potential cleavage sites (i.e., between aliphatic or aromatic amino acid side chains) buried inside the $\beta$-barrel (Dalgalarrondo et al., 1995). The core of the protein is made up of a very short $\alpha$-helix segment, coupled with 8 strands of antiparallel $\beta$-sheets, which wrap around to form the (antiparallel) $\beta$-barrel. Several authors have developed efforts aimed at understanding how physical and chemical modifications brought about by solvent changes, heat treatments, reducing agents, and esterification may enhance susceptibility of $\beta$-LG to protease action (Maeda et al., 1987; Klemaszewski and Klinsella, 1991; Schmidt and van Markwijk, 1993; Dalgalarrondo et al., 1995; Guo et al., 1995; Creamer and MacGibbon, 1996; Sitohy et al., 2001; Bertrand-Harb et al., 2002). On the other hand, $\alpha$-lactalbumin ( $\alpha$-LA) is a small, compact globular protein, which consists of 123 amino acids and is stabi- 
lized by 4 disulfide bonds; however, access to enzymes is in this case stereochemically unrestricted (Kuwajima et al., 1990).

Aqueous extracts from $C$. cardunculus flowers, either crude or partially purified, and cardosin A itself (free or immobilized) have been reported to exhibit significant proteolytic activity toward whey proteins, mainly on $\alpha$ LA, when whole whey or whey protein concentrate were used (Lamas et al., 2000; Barros et al., 2001, 2003; Barros and Malcata, 2002, 2004). Specifically, the crude extract from $C$. cardunculus exhibits proteolytic activity over a broad $\mathrm{pH}$ range (4.0 to 6.0 ), with a maximum at approximately $\mathrm{pH} 5.2$, whereas the optimum temperature lies in the vicinity of $55^{\circ} \mathrm{C}$ (our unpublished data); these findings are consistent with those reported by Campos et al. (1990), Heimgartner et al. (1990), and Faro (1991). Even though extensive work exists pertaining to action of cardosins $\mathrm{A}$ and $\mathrm{B}$ (either independently or as a mixture) on bovine caseins (Macedo et al., 1996; Ramalho-Santos et al., 1996; Sousa and Malcata, 1998; Silva and Malcata, 2004), no data relating to the (independent) action of those 2 aspartic proteinases on bovine whey proteins have, to our knowledge, been made available, especially in terms of selectivity for their peptide bonds. However, there is a body of knowledge pertaining to the activity of other aspartic proteases (pepsin) toward bovine whey proteins (Miranda and Pélissier, 1983; Reddy et al., 1988; Asselin et al., 1989; Schmidt and Poll, 1991; Kinekawa and Kitabatake, 1996; Stapelfeldt et al., 1996; Pellegrini et al., 1999; Pintado and Malcata, 2000). According to these authors, the behaviors of the 2 major whey proteins regarding hydrolysis by pepsin are rather different: $\alpha$ LA is highly susceptible to that enzyme, whereas $\beta$ LG remains essentially unchanged. More recently, ElZahar et al. (2005) have shown that both ovine $\alpha$-LA and $\beta$-LG (variants A and B) are susceptible to pepsin hydrolysis; this observation was explained on the basis of amino acid changes in the sequence of ovine $\beta$-LG when compared with its bovine counterpart, which will likely have an impact on its tertiary structure, with a concomitant increase in hydrophobicity.

The aim of the present work was 2 -fold: to evaluate the susceptibility of the major bovine whey proteins ( $\beta$-LG and $\alpha$-LA) to hydrolysis brought about by pure cardosins A and B; and to identify the specific sites of cleavage within those proteins. With regard to the latter goal, low- and high-pressure liquid chromatography methods and electrophoresis were used to resolve the main peptides released by cardosins $\mathrm{A}$ and $\mathrm{B}$, followed by chemical sequencing thereof.

\section{MATERIALS AND METHODS}

\section{Chemicals}

Pure whey proteins of bovine origin, i.e., $\alpha$-LA (L6010), prepared from raw, unpasteurized milk purified by ion exchange chromatography using DEAE-agarose, and $\beta$-LG (mixture of A and B variants, L-0130), crystallized and lyophilized 3 times, as well as azocasein, ammonium persulfate, $\mathrm{N}^{\prime} \mathrm{N}^{\prime} \mathrm{N}{ }^{\prime} \mathrm{N}$-tetramethylethylenediamine, molecular mass standards for Phast electrophoresis [BSA (66 kDa), ovalbumin ( $45 \mathrm{kDa})$, glyceraldehyde3-phosphate dehydrogenase $(36 \mathrm{kDa})$, carbonic anhydrase $(29 \mathrm{kDa})$, trypsinogen $(24 \mathrm{kDa})$, trypsin inhibitor $(20 \mathrm{kDa})$, and $\alpha$-LA $(14.2 \mathrm{kDa})]$, and dialysis tubing (with molecular mass cutoff of $10 \mathrm{kDa}$ ) were purchased from Sigma (St. Louis, MO). Sodium dihydrogen phosphate monohydrate, disodium hydrogen phosphate dihydrate, sodium chloride, citric acid monohydrate, Tris$\mathrm{HCl}, \mathrm{TCA}$, and (extra pure) sodium azide were obtained from Merck (Darmstadt, Germany). Molecular mass standards for fast protein liquid chromatography [FPLC; aldolase (158 kDa), BSA (67 kDa), ovalbumin (43 kDa), $\beta$-LG (36 kDa), $\alpha$-LA, and ribonuclease (13.7 $\mathrm{kDa})$ ]; medium molecular mass standards for SDSPAGE [phosphorylase B (94 kDa), BSA, ovalbumin, carbonic anhydrase $(30 \mathrm{kDa})$, soybean trypsin inhibitor $(20.1 \mathrm{kDa})$, and $\alpha-\mathrm{LA}$; and low molecular mass standards [globin $(16.9 \mathrm{kDa})$, globin I+II $(14.4 \mathrm{kDa})$, globin I+III (10.7 kDa), globin (8.2 kDa), globin II (6.2 kDa), and globin III (2.5 kDa)]; as well as blue dextran, were obtained from Pharmacia (Uppsala, Sweden). Sodium dodecyl sulfate, $\beta$-mercaptoethanol, and tricine [N-tris(hydroxymethyl)methyl-glycine], as well as polyvinylidene difluoride membranes (ProBlot), were purchased from BioRad (Hercules, CA). Filter paper $(0.22 \mu \mathrm{m})$ was obtained from Nalgene (New York, NY), and nonsterile filters $(0.45 \mu \mathrm{m})$ from Nucleopore (Cambridge, MA). Tap water was purified in a Milli-Q Plus 185 system (Molsheim, France) to a final conductivity of $\sim 18.2 \mathrm{M} \Omega /$ $\mathrm{cm}$. The solvents used were analytical grade or better, and were used without further purification.

\section{Equipment}

The FPLC system consisted of 2 P-500 positive displacement pumps, an electrically powered MV-7 motorized valve, and an UVII single-path spectrophotometer monitor from Amersham Pharmacia Biotech (Uppsala, Sweden). To perform purification, a Sephacryl S-200 HR 16/60 column followed by a Q-Sepharose-HiTrap column (5 mL each; Amersham Pharmacia Biotech) was used. To evaluate hydrolysis, a Superose 12 HR 10/30 column (Amersham Pharmacia Biotech) was selected. The purified enzyme fractions were lyophilized in a Christ Alpha 1-4 freeze-dryer, from Braun Biotech (Braunschweig, Germany).

Reverse phase-HPLC (RP-HPLC) was performed in an Alliance 2690 HPLC model system, equipped with a separation module 2690, an auto injector, and a photo- 
diode array detection system model 996 (Waters, Milford, MA). A Lichrosphere $\mathrm{C}_{8}$ column $(4.6 \times 250 \mathrm{~mm})$, containing $5-\mu \mathrm{m}$ particles, coupled with a Lichrocart 44 guard column, were purchased from Merck.

Sodium dodecyl sulfate-PAGE was performed in a Protean II xi vertical slab-gel unit, coupled with a model 1000/500 power supply (BioRad, Watford, UK), and a refrigerated water bath (Julabo Labortechnik, Seelbach, Germany). High-density electrophoresis gels were run using a PhastSystem unit (Amersham Pharmacia Biotech). Electroblotting was performed using a mini TransBlot electrophoretic transfer cell (BioRad, Hercules, CA).

$N$-Terminal chemical sequencing was performed with a Procise 491 automated, pulsed liquid-phase protein/ peptide sequencer (Applied Biosystems, Foster City $\mathrm{CA}$ ), with chemicals and software supplied by the manufacturer.

\section{Extraction and Purification of Enzymes}

The crude enzyme extract was prepared by macerating dried flowers of $C$. cardunculus with citrate buffer (at pH 3.0); the supernatant, following centrifugation, was loaded onto a Sephacryl gel filtration column, as described in detail by Barros and Malcata (2002). This step was repeated as many times as necessary to obtain preparative amounts of the enzymatically active fraction of the crude extract. After gel filtration, the fraction collected was loaded onto 2 anion-exchange Q-Sepharose-Hitrap columns installed in series, equilibrated with $20 \mathrm{~m} M$ Tris-HCl buffer (at $\mathrm{pH}$ 7.6). The active enzyme fractions were eluted at a flow rate of $5.0 \mathrm{~mL} /$ min under a (previously optimized) gradient of $0.5 \mathrm{M}$ $\mathrm{NaCl}$, with equilibration with buffer for the first $2 \mathrm{~min}$, linear increase to $20 \%$ (vol/vol) $\mathrm{NaCl}$ over 1 min, linear increase to $45 \%$ (vol/vol) $\mathrm{NaCl}$ over $9 \mathrm{~min}$, holding for $1 \mathrm{~min}$, linear increase to $100 \%$ (vol/vol) over $3 \mathrm{~min}$, and holding for $4 \mathrm{~min}$. An injection loop of $10 \mathrm{~mL}$ was used, and detection of proteins in the eluate was by continuous recording of absorbance at $280 \mathrm{~nm}$. The active fractions (corresponding to cardosins A and B) were collected, and dialyzed for $48 \mathrm{~h}$ at $4^{\circ} \mathrm{C}$ against an excess volume of deionized water. After collection, presence of the enzymes in each fraction was confirmed by electrophoresis (using Phastgel-High density gels), and quantified in terms of protease activity using azocasein as substrate. Finally, the active and pure fractions were lyophilized and then frozen at $-20^{\circ} \mathrm{C}$ until use.

\section{Determination of Protein Content of Enzymes}

The total protein content of the fractions was measured using a Micro Protein determination kit (A-690,
Sigma), based on the Lowry procedure (Lowry et al., 1951), which uses Folin-Ciocalteu's phenol reagent. Assays were carried out in triplicate, and their average was taken as a datum point.

\section{Determination of Catalytic Activity of Enzymes}

The proteolytic activity of pure cardosins was determined according to the method of Tomarelli et al. (1949) with slight modification that involved digestion of azocasein (a casein derivative containing a dinitrogenated arylamine chromophore). Quantification of the proteolytic activity was based on the amount of peptides released as monitored by absorbance units at $440 \mathrm{~nm}$, according to Barros et al. (2001). All assays were carried out in triplicate, and their average was taken as a datum point. The proteolytic activities of cardosins A and $\mathrm{B}$, expressed as variation of absorbance at $440 \mathrm{~nm}$ per gram of protein per minute ( \pm standard error), were $1.42 \pm 0.32$ and $2.33 \pm 0.19$, respectively.

\section{Performance of Enzyme-Mediated Hydrolysis}

All experiments were carried out in a water bath, shaken at $100 \mathrm{rpm}$, and kept at $55^{\circ} \mathrm{C}$. The protein aqueous solutions ( $15 \mathrm{~mL}$ ) were prepared by dissolving $2.4 \%$ (wt/vol) of substrate in $100 \mathrm{~m} M$ sodium citrate buffer ( $\mathrm{pH}$ 5.2); these conditions were chosen to mimic the best conditions for whole whey protein hydrolysis by cardosins (Barros and Malcata, 2002). Enzymatic hydrolysis was started by addition of given amounts of cardosin A or cardosin B solutions, as appropriate. All experiments had a control, which was run under similar conditions but without enzyme, to confirm whether hydrolysis was only a result of the corresponding enzyme. Furthermore, sodium azide was added in all experiments to a final concentration of $0.5 \%$ (wt/vol), to prevent microbial growth.

\section{Analysis by Low-Pressure Chromatography}

Hydrolysis products of $\beta$-LG and $\alpha$-LA were assayed by FPLC, as described previously by Barros et al. (2001).

\section{Analysis by High-Pressure Chromatography}

Release of peptides by hydrolysis of $\beta$-LG and $\alpha$-LA was monitored by RP-HPLC, as described by Barros et al. (2003). Samples were filtered through $0.22-\mu \mathrm{m}$ cellulose acetate filters, and kept under refrigeration $\left(10^{\circ} \mathrm{C}\right)$; an aliquot $(100 \mu \mathrm{L})$ of filtrate was then injected onto the column, and detection was by absorbance at $214 \mathrm{~nm}$. Previous calibration of the column indicated 
retention times of $59 \mathrm{~min}$ for $\alpha$-LA and 63 to $65 \mathrm{~min}$ for $\beta$-LG. The most significant peaks, putatively corresponding to peptides, were collected manually, freezedried, and stored at $-20^{\circ} \mathrm{C}$ until use.

\section{Analysis by Electrophoresis}

Tricine-SDS-PAGE (16.5\%) was run as reported by Barros et al. (2003). In each run, a set of medium- and low-molecular mass standards was applied. Qualitative and quantitative analyses of electrophoretograms were made by densitometric scanning, using a green filter in a GS-700 imaging densitometer, and further analyzed using the image analysis software Molecular Analyst (BioRad).

\section{Analysis by Peptide Sequencing}

After electrophoresis, gels were blotted to polyvinylidene difluoride membranes (pore size $0.22 \mu \mathrm{m}$ ), using a buffer containing $25 \mathrm{~m} M$ Tris, $192 \mathrm{~m} M$ glycine, $0.01 \%$ (wt/vol) SDS, and $200 \mathrm{~mL}$ of methanol (pH 8.0). Blotting was performed for $1 \mathrm{~h}$ at $100 \mathrm{~V}$. Selected low-molecular mass peptides were collected manually from the outlet of the RP-HPLC used for their resolution; these fractions were then applied to a polyvinylidene difluoride membrane, and dried. In both cases, membranes were rinsed with water, stained for 15 min using $2 \mathrm{~g}$ of Coomassie blue R250 in $450 \mathrm{~mL}$ of methanol, and destained with methanol for $30 \mathrm{~min}$. The bands were then excised from the membrane, and subjected to amino-terminal sequencing by automated Edman degradation, using a model 491A protein sequencer (Applied Biosystems). The partial sequences thus obtained were checked against the (known) sequences of $\alpha$-LA, to determine which peptide bonds were cleaved by cardosins A and $\mathrm{B}$, respectively.

\section{RESULTS AND DISCUSSION}

\section{Quantitative Characterization of Hydrolysis}

Several analytical techniques have been extensively used in the characterization of protein hydrolyzates. Fast protein liquid chromatography-gel filtration and SDS-PAGE are currently used as accurate and efficient processes to evaluate and monitor protein degradation; in addition, they allow determination of the molecular mass of concomitantly appearing medium-size peptides. Furthermore (and unlike SDS-PAGE), FPLC analysis does not involve application of any reducing agent, hence confirming absence of formation of aggregates or denaturation phenomena (Figures 1 and 2). The behavior of cardosins $\mathrm{A}$ and $\mathrm{B}$, in terms of extent of hydrolysis of $\alpha$-LA and $\beta$-LG at $55^{\circ} \mathrm{C}$ and $\mathrm{pH} 5.2$, was evaluated by FPLC (see Figures 1 and 2). Analysis based on changes in peak areas, relative to intact $\alpha$ LA, indicated that this protein vanished rapidly, especially in the presence of cardosin B (Figure 1b). The peptide profiles were rather dynamic, which unfolds the availability of several peptide bonds in $\alpha$-LA to sequential attack by cardosin B (unlike what is observed for cardosin A, Figure 1a,b). Figure 1b shows that cardosin B generated 5 major (polypeptide) peaks, which were eluted at relatively long retention times (38 to $49 \mathrm{~min}$ ). According to the calibration of the column, those peaks possess a molecular mass between 2.5 and $9 \mathrm{kDa}$; a high overall proportion of 3 of those peaks (i.e., $~ 9,5$, and $3 \mathrm{kDa}$ ) is also apparent. By $24 \mathrm{~h}$ of incubation, another (small) peak at $\sim 61 \mathrm{~min}$ appears, which corresponds to a short peptide $(<1 \mathrm{kDa})$ and is likely a result of cleavage of polypeptides generated in the interval.

Unlike the activity of cardosins on $\alpha$-LA, neither cardosin hydrolyzed $\beta$-LG (Figure 2), because the corresponding peak area remains essentially unchanged up to $24 \mathrm{~h}$ of incubation. Previous studies (Lamas et al., 2000; Barros et al., 2001; Barros and Malcata, 2002) reported a significantly lower affinity of cardosins toward $\beta$-LG than to $\alpha$-LA, when whole whey and crude plant extract were used. Furthermore, Barros and Malcata (2004) showed that $\alpha$-LA and $\beta$-LG were differently acted upon by cardosin $\mathrm{A}$, when present together; $\alpha$ LA was hydrolyzed at a much higher rate and to a greater extent than $\beta$-LG. Similar results were observed with pepsin (another aspartic protease) from different sources, which converts $\alpha$-LA rapidly (within 30 min) into small peptides while leaving $\beta$-LG almost unhydrolyzed (Miranda and Pélissier, 1983; Reddy et al., 1988; Schmidt and Poll, 1991). Although substrate competition for the active site was hypothesized previously (Barros and Malcata, 2002), our results utilizing pure proteins show an apparent incapacity of cardosins to hydrolyze $\beta$-LG; this suggests severe hampering of enzyme access to the cleavage site(s), probably as a result of a strong hydrophobic core. Dalgalarrondo et al. (1995) revealed that hydrophobic and aromatic amino acid side chains (which are potential peptic cleavage sites) in bovine $\beta$-LG are buried well inside the $\beta$ barrel, thus forming a strong hydrophobic core. Conversely, ovine $\beta$-LG possesses a high surface hydrophobicity due to the presence of 5 amino acid changes in primary structure; this appears to be sufficient to enhance its susceptibility to pepsin attack (El-Zahar et al., 2005). It is well known that the induced structural transformations increase $\beta$-LG susceptibility to protease action, by destabilizing the tertiary structure and the hydrophobic core of $\beta$-LG, and thus exposing the apolar amino acid side chains (Klemaszewski and 
a)
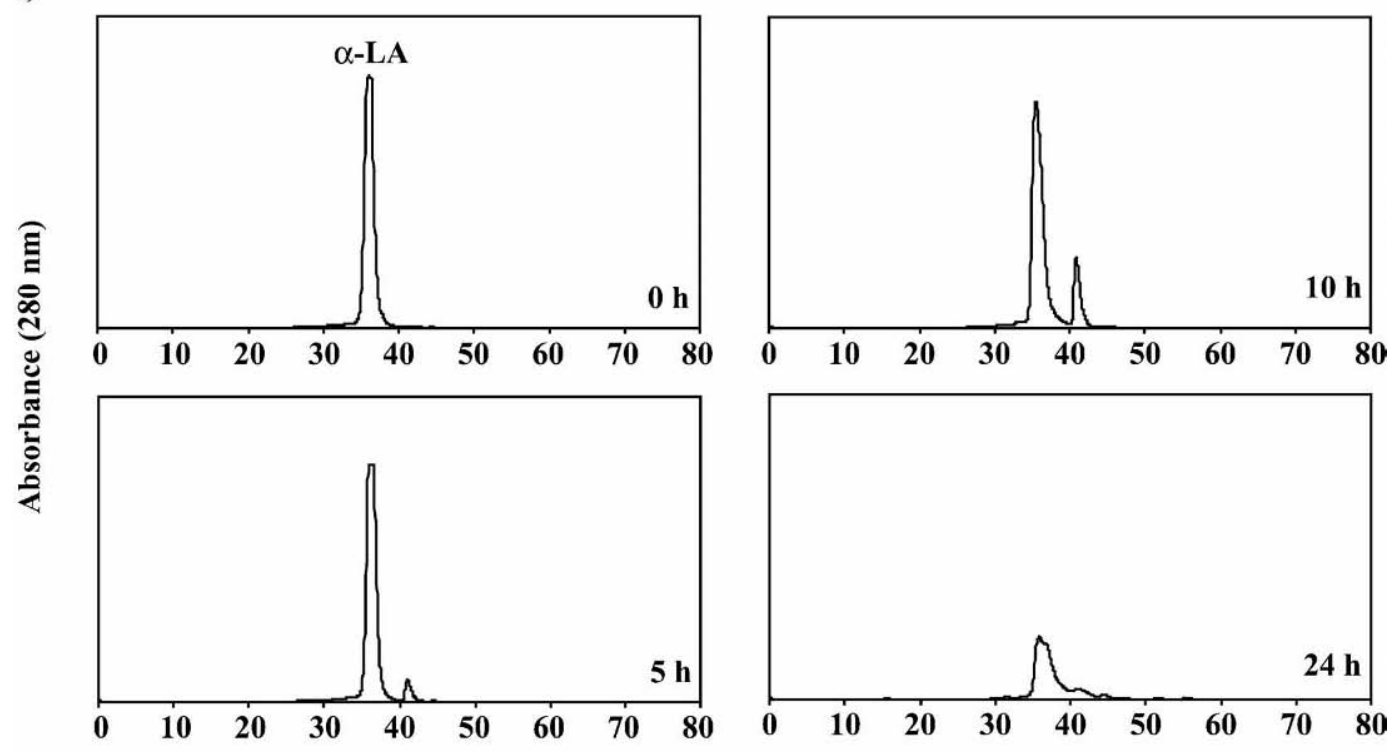

b)
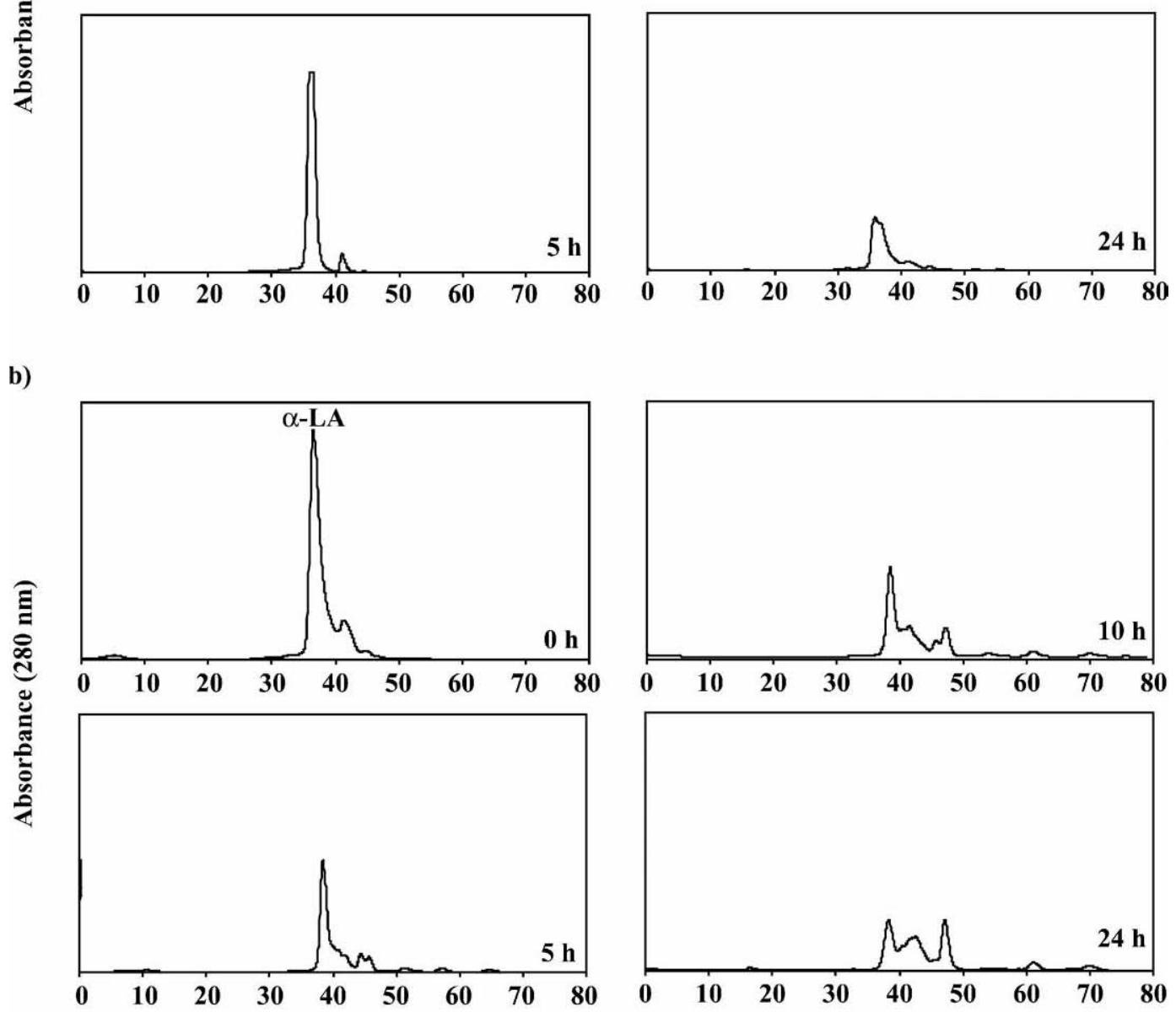

Elution time (min)

Figure 1. Elution profile by fast protein liquid chromatography of hydrolyzates for various incubation times of $\alpha$-LA effected by a) cardosin $\mathrm{A}$, and b) cardosin $\mathrm{B}$ at an enzyme to substrate ratio of $1 / 250$ (wt/wt), $55^{\circ} \mathrm{C}$, and $\mathrm{pH} 5.2$.

Klinsella, 1991; Schmidt and van Markwijk, 1993; Dalgalarrondo et al., 1995; Creamer and MacGibbon, 1996; Bertrand-Harb et al., 2002). These conformational changes are favorable to protein unfolding (denaturation) and enhance aggregation of proteins via intermolecular bridging. However, the FPLC profiles (Figures 1 and 2) provided evidence that such aggregates from each whey protein did not form.
The results of hydrolysis of $\alpha$-LA by cardosins A and B, monitored by Tricine SDS-PAGE, are plotted in Figure 3, parts a and b, respectively. Cardosin A exhibits considerable activity toward $\alpha$-LA; by $1 \mathrm{~h}$, it was possible to detect 2 peptide fragments, $\mathrm{A}$ and $\mathrm{D}$, with molecular masses of $\sim 8$ and $5 \mathrm{kDa}$ (with a higher band intensity for the former). By $10 \mathrm{~h}, 2$ more bands could be detected (B and $\mathrm{C}$ ), with molecular masses of $\sim 7.1$ and $6.5 \mathrm{kDa}$; 
a)
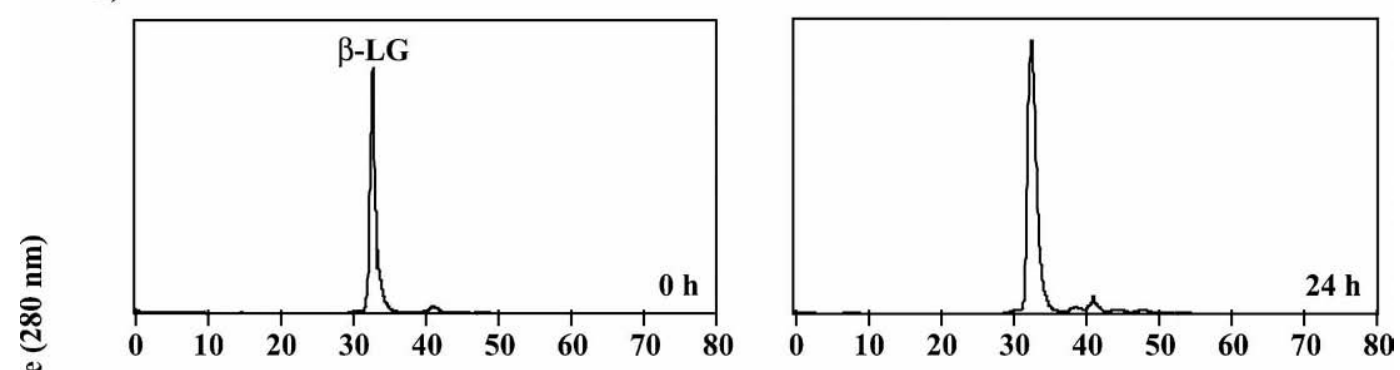

b)
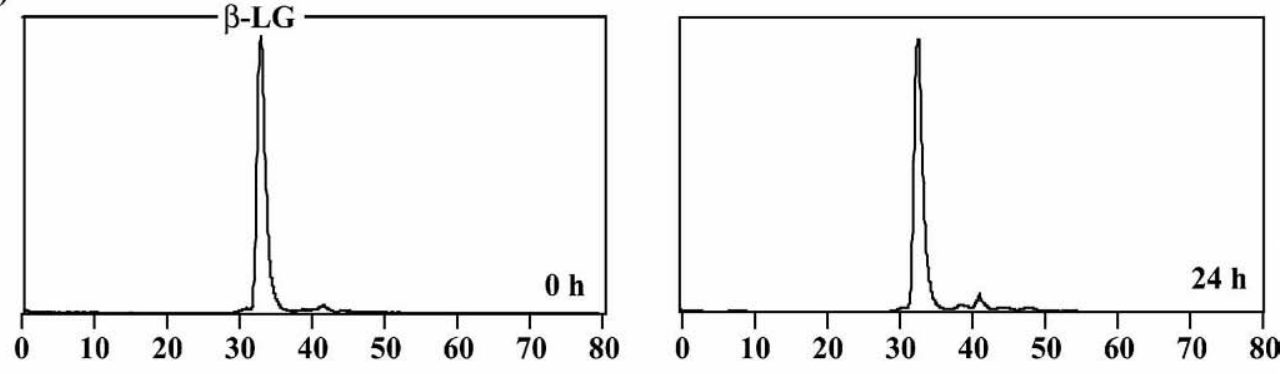

Elution time (min)

Figure 2. Elution profile by fast protein liquid chromatography of hydrolyzates for various incubation times of $\beta$-LG effected by a) cardosin $\mathrm{A}$, and b) cardosin $\mathrm{B}$ at an enzyme to substrate ratio of $1 / 250$ (wt/wt), $55^{\circ} \mathrm{C}$, and $\mathrm{pH} 5.2$.

these might be the result of breakdown of fragment A. Furthermore, a continuous increase in intensity of band D seemed to correlate with the continuous disappearance of the band accounted for by $\alpha$-LA. Another band (identified as E), with a molecular mass of $\sim 3 \mathrm{kDa}$, became visible by $24 \mathrm{~h}$, when $\alpha$-LA existed only in residual amounts. Recalling the results by Barros and Malcata (2004), we concluded that cardosin A acts on $\alpha$-LA in a similar fashion irrespective of $\alpha$-LA being pure or mixed in whole whey; hence, resulting in a similar lowand medium-peptide pattern (between $\sim 3$ and $8 \mathrm{kDa}$ ). On the other hand, inspection of Figure $3 \mathrm{~b}$ reinforced the belief that cardosin $\mathrm{B}$ also possesses activity toward $\alpha$-LA, even higher than that of cardosin A. By $1 \mathrm{~h}, 6$ bands could be ascertained (A to F), with molecular masses in the range of 3 to $8 \mathrm{kDa}$ (Figure $3 \mathrm{~b}$ ). The lowand medium-sized peptides released by cardosin $B$ from $\alpha$-LA are similar to those generated by cardosin A; however, the former were released faster, and led to appearance of an (intermediate) extra band. Furthermore, no intact $\alpha$-LA was detected after $5 \mathrm{~h}$. Cardosin B also showed a substantial capacity to hydrolyze the peptides initially formed by $24 \mathrm{~h}$, as only 2 of those peptides were still visible by this time (Figure $3 \mathrm{~b}$, lanes 3 to 5); bands $\mathrm{B}$ and $\mathrm{F}$ became more intense as time elapsed, whereas the remaining bands disappeared by $24 \mathrm{~h}$ (see bands A, C, D, and E in Figure 3b). The limitations of this analytical technique imply that (the expected) concomitant formation of peptides with molecular mass $<2.5 \mathrm{kDa}$ is not visible. Finally, it is important to emphasize that $\alpha$-LA was hydrolyzed to a similar extent, in either isolated form or in whole whey, by cardosins $\mathrm{A}$ and $\mathrm{B}$; in both cases, the controls confirmed that $\alpha$ LA would remain unaltered if no cardosin were added (Barros and Malcata, 2002).

Complementary electrophoresis experiments showed that $\beta$-LG remained intact in the presence of either cardosin A or B after incubation for up to $24 \mathrm{~h}$ (data not shown). These results are consistent with previous studies (Lamas et al., 2000; Barros et al., 2001; Barros and Malcata, 2002, 2004), which showed that crude plant extract (containing a mixture of cardosins) exhibits a remarkably low ability and affinity to hydrolyze $\beta$-LG, when whole bovine whey was considered. Our results confirm those reported previously by Barros and Malcata (2002), who found $K_{m}$ values for cardosins A and $\mathrm{B}$ acting on $\alpha$-LA ( $\mathrm{pH} 5.2,55^{\circ} \mathrm{C}$ ) to be substantially lower than those for cardosins acting on $\beta$-LG. The higher resistance of $\beta$-LG to hydrolysis by various enzymes (including cardosins) has been discussed to some length, and is normally attributed to its globular conformation and particular folding pattern; in fact, 2 disulfide bonds build a tough hydrophobic core, which consequently hampers access of enzymes to potential cleavage sites (i.e., hydrophobic or aromatic amino acid side chains; Dalgalarrondo et al., 1995). 
a)

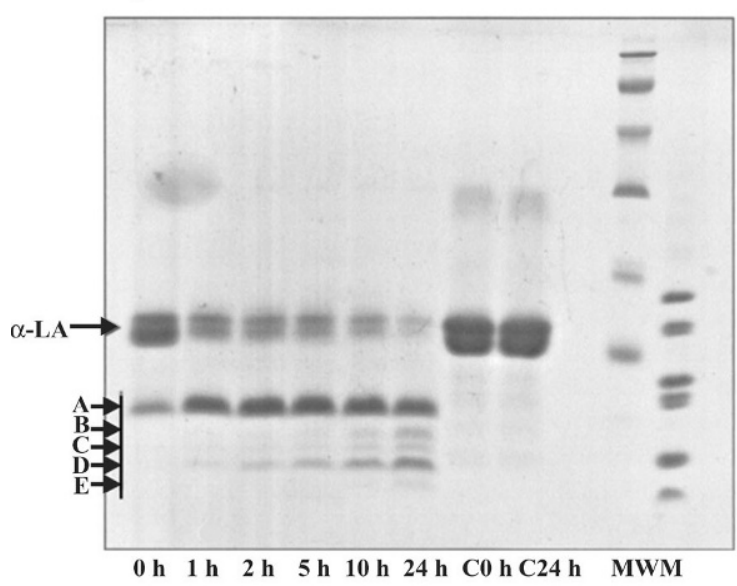

b)

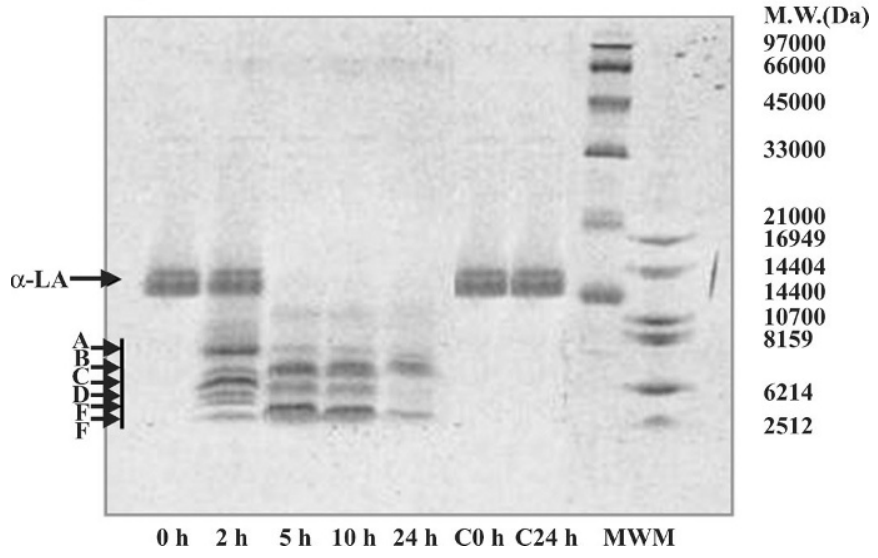

Figure 3. Separation profile by electrophoresis of hydrolyzates of $\alpha$-LA for various incubation times (lettered arrows indicate peptides released) with a) cardosin $\mathrm{A}$, and b) cardosin $\mathrm{B}$ at an enzyme to substrate ratio of $1 / 250$ (wt/wt), $55^{\circ} \mathrm{C}$, and $\mathrm{pH} 5.2$. Controls (at 0 , $\mathrm{C} 0 \mathrm{~h}, 24 \mathrm{~h}$, and $\mathrm{C} 24 \mathrm{~h}$ ) are included, along with molecular weight markers (MWM).

Analysis by HPLC was important for resolution of small peptides (with molecular mass $<2.5 \mathrm{kDa}$ ), and to complement the information on the behavior of each cardosin toward the small peptides released throughout incubation. Furthermore, HPLC that uses hydrophobic (or reverse phase) columns permits efficient separation of small peptides (which are formed as part of secondary proteolysis), while providing useful information regarding their hydrophobicity. The data encompassing action on $\alpha$-LA by cardosins A and B vs. time, as monitored by RP-HPLC, are depicted in Figure 4. Inspection of this figure reveals that cardosins $\mathrm{A}$ and $\mathrm{B}$ have a different behavior toward $\alpha$-LA: based on FPLC and SDS-PAGE data, cardosin B hydrolyzes $\alpha$-LA faster than does cardosin A, and no intact $\alpha$-LA can be detected by $10 \mathrm{~h}$ (unlike hydrolysis with cardosin A). However, there is a relative stability of the peptide profiles, with only minor alterations brought about by cardosin A (in contrast to what was observed during hydrolysis by cardosin $\mathrm{B}$ ); this demonstrates simultaneous availability of most cleavage sites in $\alpha$-LA to cardosin B action. A slow increase in concentration of the few peptides generated can be observed in Figure $4 \mathrm{a}$; after $10 \mathrm{~h}$ of incubation, 3 relatively large peaks can be detected, 2 of which were eluted in the hydrophilic region $(\sim 32$ $\mathrm{min})$, whereas the other one had a longer retention time $(\sim 62 \mathrm{~min})$. By $24 \mathrm{~h}$, presence of a few extra peaks was also apparent.

Cardosin A appears to be extremely specific in its action, with an apparent incapacity to rehydrolyze fragments already formed into smaller peptide fragments. Cardosin B shows a broad activity, as apparent from the high number of peaks detected, in contrast with those obtained via cardosin A (Figure 4). The major peptide released by cardosin $\mathrm{B}$ after $10 \mathrm{~h}$ of incubation elutes at $\sim 56$ min (Figure $4 \mathrm{~b}$ ); however, this peptide seems to be broken down over the full reaction time frame. The evolution pattern of this peptide, coupled with the hydrophobic nature of its elution zone, suggests its association with the fragment denoted as $\mathrm{B}$ $(\sim 7.2 \mathrm{kDa})$ in Figure $3 \mathrm{~b}$. After $24 \mathrm{~h}$ of incubation, the peptide profile had evolved considerably; there was a general decrease in area of the highest peaks observed by $10 \mathrm{~h}$, with a simultaneous increase in peak area at lower retention times (associated with hydrophilic peptides). The chromatogram obtained after $10 \mathrm{~h}$ contains 2 peaks, which elute between 45 and $47 \mathrm{~min}$, and eventually disappear by $24 \mathrm{~h}$ of incubation. This observation seems to correlate with disappearance of bands labeled C and D (see Figures $3 \mathrm{~b}$ and $4 \mathrm{~b}$ ). It is possible to observe in Figure $4 \mathrm{~b}$ that the largest peak obtained after $24 \mathrm{~h}$ of incubation (at $\sim 51 \mathrm{~min}$ ) had increased considerably relative to its 10 -h counterpart; this evolution pattern justifies correspondence to the polypeptide characterized by a molecular mass of $\sim 3.1$ $\mathrm{kDa}$ (labeled as $\mathrm{F}$ in Figure $3 \mathrm{~b}$ ).

\section{Qualitative Characterization of Hydrolysis}

Analysis of the primary structure of individual peptides allows identification of sites of cleavage by cardosins by comparison with the complete (and known) sequence of their substrate protein (i.e., $\alpha$-LA). Six peptides that were visible by electrophoresis (labeled A to $\mathrm{F}$ in Figure 3b) were sequenced by Edman degradation following electroblotting; their $\mathrm{N}$-terminal sequences are shown in Table 1. As already stated, hydrolysis of $\alpha$-LA generates initially 2 peptide fragments, designated $\mathrm{A}$ and $\mathrm{E}$, because of the catalytic action of cardosin B on bonds Leu71-Phe72 and Ala19-Glu20, re- 

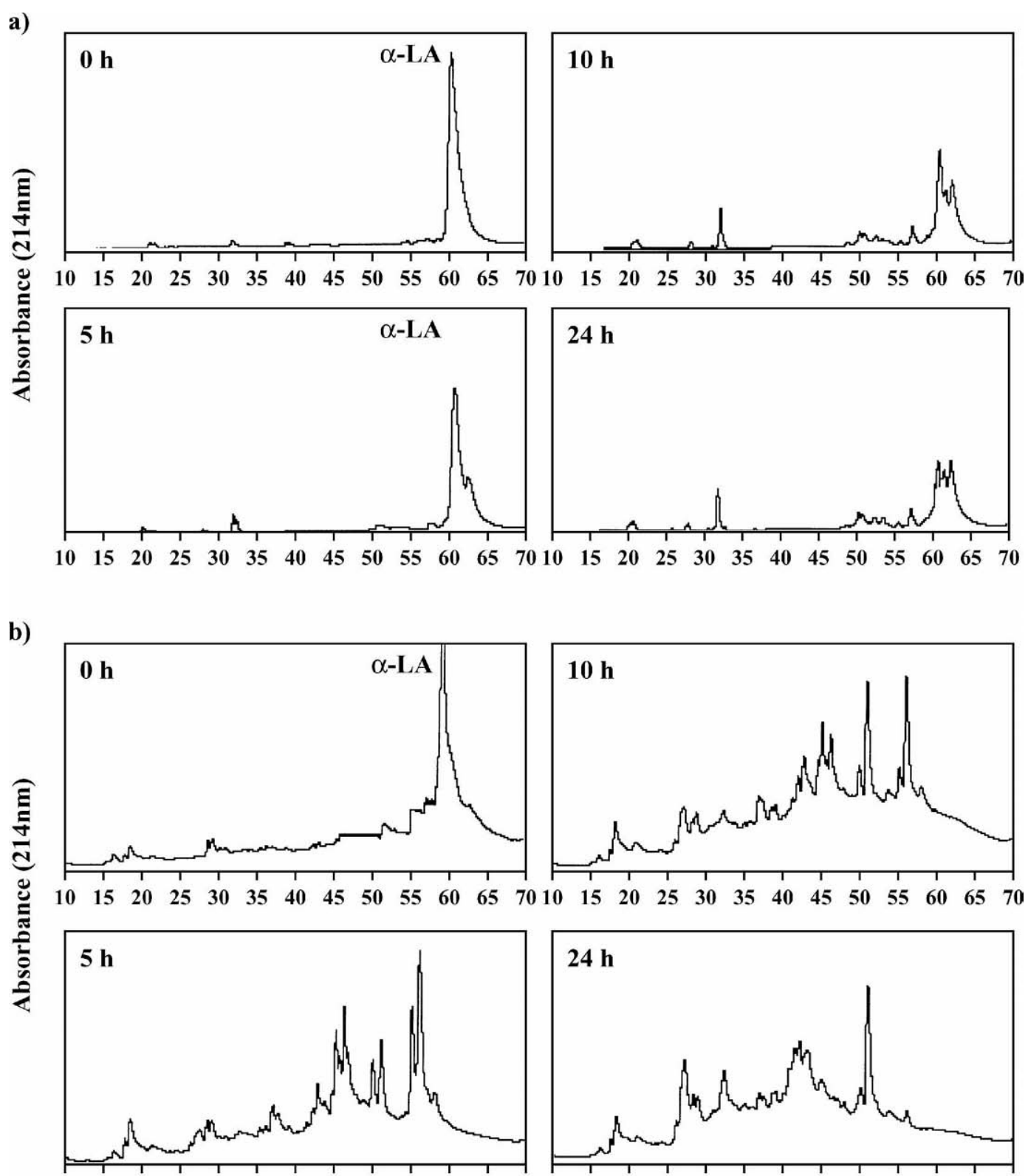

$24 \mathrm{~h}$

$\begin{array}{lllllllllllllllllllllllllll}10 & 15 & 20 & 25 & 30 & 35 & 40 & 45 & 50 & 55 & 60 & 65 & 70 & 10 & 15 & 20 & 25 & 30 & 35 & 40 & 45 & 50 & 55 & 60 & 65 & 70\end{array}$

Elution time (min)

Figure 4. Elution profile by reverse-phase HPLC of hydrolyzates for various incubation times of $\alpha$-LA effected by a) cardosin A, and b) cardosin $\mathrm{B}$ at an enzyme to substrate ratio of $1 / 250$ (wt/wt), $55^{\circ} \mathrm{C}$, and $\mathrm{pH} 5.2$.

spectively. $\alpha$-Lactalbumin was also cleaved by cardosin $\mathrm{B}$ at bond Phe72-Gln73, releasing fragments B, C, and $\mathrm{F}$, which probably result from further hydrolysis of the initial fragment A.

Regarding resolution by RP-HPLC of the hydrolyzates of $\alpha$-LA brought about by cardosin A (Figure 4a), the N-terminal sequences of the peptides (Table 1) indicated that $\alpha$-LA was also cleaved by cardosin $\mathrm{A}$ at bonds Phe28-Arg29, Gly54-Tyr55, Ala59-Ile60, Leu71-Phe72, and Leu105-Thr106. The peptides that account for peaks 5 and 6 (Figure 5a; Table 1) possess the same $9 \mathrm{~N}$ terminal residues, so they might result from the same peptide (band A; Figure 3b).

The N-terminal amino acid sequences of peptides apparent in Figure $4 \mathrm{~b}$ are also listed in Table 1. It should be noted that $\alpha$-LA was cleaved by cardosin B at bonds Ala19-Glu20, Phe28-Arg29, Glu30-Leu31, Tyr37Gly38, Trp45-Val46, Phe50-His51, Ala59-Ile60, Ser66- 
Table 1. Amino acid sequence of peptides in hydrolyzates of $\alpha$-LA, effected by cardosin A and by cardosin B isolated by reverse phase-HPLC, and by cardosin B isolated by electroblotting

\begin{tabular}{|c|c|c|c|c|}
\hline Enzyme & Peak & $\begin{array}{l}\text { Retention } \\
\text { time } \\
(\mathrm{min})\end{array}$ & Sequence & $\begin{array}{l}\text { Proposed } \\
\text { fragment }\end{array}$ \\
\hline \multirow[t]{6}{*}{ Cardosin A } & 1 & 22 & $\mathrm{H}_{2} \mathrm{~N}$-Arg-Glu-COOH & f $29-30$ \\
\hline & 2 & 29 & $\mathrm{H}_{2} \mathrm{~N}$-Ile-Val-Gln-Asn-Asn-Asp-Ser-Thr-...? & f $60-\ldots ?$ \\
\hline & 3 & 34 & $\mathrm{H}_{2} \mathrm{~N}$-Tyr-Asp-Thr-Gln-Ala-Ile-Val-...? & f $55-\ldots ?$ \\
\hline & 4 & 52 & $\mathrm{H}_{2} \mathrm{~N}$-Asp-Asp-Ile-Met-Cys-Val-Lys-Lys-...? & f $106-\ldots ?$ \\
\hline & 5 & 58 & $\mathrm{H}_{2} \mathrm{~N}$-Phe-Gln-Ile-Asn-Asn-Lys-Ile-Trp-Cys-...? & f $72-\ldots ?$ \\
\hline & 6 & 64 & $\mathrm{H}_{2} \mathrm{~N}$-Phe-Gln-Ile-Asn-Asn-Lys-Ile-Trp-Cys-...? & f $72-\ldots ?$ \\
\hline \multirow[t]{29}{*}{ Cardosin B } & 1 & 18 to 20 & $\mathrm{H}_{2} \mathrm{~N}-\mathrm{His}$-Thr-Ser-Gly-Tyr-Asp-Thr-Gln-...? & f $51-\ldots ?$ \\
\hline & 2 & & $\mathrm{H}_{2} \mathrm{~N}-\mathrm{Arg}$-Glu-Leu-Lys-Asp-Leu-Lys-Gly-COOH & f $29-37$ \\
\hline & 3 & 25 & $\mathrm{H}_{2} \mathrm{~N}$-Leu-Lys-Asp-Leu-Lys-Gly-Tyr-Gly-...? & f $31-\ldots ?$ \\
\hline & & & $\mathrm{H}_{2} \mathrm{~N}$-Val-Cys-Thr-Thr-Phe-COOH & f $46-50$ \\
\hline & 4 & 26 to 27.9 & $\mathrm{H}_{2} \mathrm{~N}-\mathrm{Arg}$-Glu-Leu-Lys-Asp-Leu-Lys-Gly-...? & f $29-\ldots ?$ \\
\hline & & & $\mathrm{H}_{2} \mathrm{~N}-\mathrm{Asp}-L y s-V a l-G l y-I l e-A s n-T y r-T r p-\ldots ? ?$ & f $116-\ldots ?$ \\
\hline & 5 & 28 to 28.5 & $\mathrm{H}_{2} \mathrm{~N}$-Ile-Val-Gln-Asn-Asn-Asp-Ser-Thr-...? & f $60-\ldots ?$ \\
\hline & & & $\mathrm{H}_{2} \mathrm{~N}$-Asp-Lys-Val-Gly-Ile-Asn-Tyr-Trp-...? & f $29-\ldots ?$ \\
\hline & 6 & 29 & $\mathrm{H}_{2} \mathrm{~N}-$-Ile-Val-Gln-Asn-Asn-Asp-Ser-Thr-...? & f $60-\ldots ?$ \\
\hline & 7 & 31 & $\mathrm{H}_{2} \mathrm{~N}-\mathrm{Thr}-\mathrm{Glu}-\mathrm{Tyr}-\mathrm{Gly}-\mathrm{COOH}$ & f $67-71$ \\
\hline & 8 & 32 to 33 & $\mathrm{H}_{2} \mathrm{~N}$-Ala-His-Lys-Ala-Leu-Cys-Ser-Glu-...? & f $125-\ldots ?$ \\
\hline & 9 & 35.5 to 36 & $\mathrm{H}_{2} \mathrm{~N}$-Ile-Val-Gln-Asn-Asn-Asp-Ser-Thr-COOH & f $60-66$ \\
\hline & 10 & 36 & $\mathrm{H}_{2} \mathrm{~N}$-Ala-His-Lys-Ala-Leu-Cys-Ser-Glu-...? & f $125-\ldots ?$ \\
\hline & 11 & 39 & $\mathrm{H}_{2} \mathrm{~N}-\mathrm{Glu}$-Gln-Leu-Thr-Lys-Cys-Glu-Val-...? & f $20-\ldots ?$ \\
\hline & & & $\mathrm{H}_{2} \mathrm{~N}-\mathrm{Ala}-\mathrm{His}-L y s-A l a-L e u-C y s-S e r-G l u-\ldots ?$ & f $125-\ldots ?$ \\
\hline & 12 & 40 & $\mathrm{H}_{2} \mathrm{~N}-\mathrm{Glu}-\mathrm{Gln}-\mathrm{Leu}-\mathrm{Th}$-Lys-Cys-Glu-Val-...? & f $20-\ldots ?$ \\
\hline & & & $\mathrm{H}_{2} \mathrm{~N}$-Ala-His-Lys-Ala-Leu-Cys-Ser-Glu-...? & f $125-\ldots ?$ \\
\hline & 13 & 41.5 & $\mathrm{H}_{2} \mathrm{~N}-\mathrm{Glu}-\mathrm{Gln}-\mathrm{Leu}-\mathrm{Th}$-Lys-Cys-Glu-Val-...? & f $20-\ldots ?$ \\
\hline & 14 & 42 to 43 & $\mathrm{H}_{2} \mathrm{~N}-\mathrm{Glu}-\mathrm{Gln}-\mathrm{Leu}-\mathrm{Th}$-Lys-Cys-Glu-Val-...? & f $20-\ldots ?$ \\
\hline & 15 & & $\mathrm{H}_{2} \mathrm{~N}-\mathrm{Glu}-\mathrm{Gln}-\mathrm{Leu}-\mathrm{Th}$-Lys-Cys-Glu-Val-...? & f $20-\ldots ?$ \\
\hline & & & $\mathrm{H}_{2} \mathrm{~N}$-Ala-His-Lys-Ala-Leu-Cys-Ser-Glu-...? & f $125-\ldots ?$ \\
\hline & 16 & 45 & $\mathrm{H}_{2} \mathrm{~N}-\mathrm{Glu}$-Gln-Leu-Thr-Lys-Cys-Glu-Val-...? & f $20-\ldots ?$ \\
\hline & & & $\mathrm{H}_{2} \mathrm{~N}$-Ala-His-Lys-Ala-Leu-Cys-Ser-Glu-...? & f $125-\ldots ?$ \\
\hline & 17 & 46 & $\mathrm{H}_{2} \mathrm{~N}-\mathrm{Glu}-\mathrm{Gln}-\mathrm{Leu}-\mathrm{Th}$-Lys-Cys-Glu-Val-...? & f $20-\ldots ?$ \\
\hline & & & $\mathrm{H}_{2} \mathrm{~N}$-Ala-His-Lys-Ala-Leu-Cys-Ser-Glu-...? & f $125-\ldots ?$ \\
\hline & 18 & 49.5 to 50 & $\mathrm{H}_{2} \mathrm{~N}$-Gln-Ile-Asn-Asn-Lys-Ile-Trp-Cys-...? & f $125-\ldots ?$ \\
\hline & 19 & & $\mathrm{H}_{2} \mathrm{~N}-\mathrm{Glu}-\mathrm{Gln}-\mathrm{Leu}-\mathrm{Th}$-Lys-Cys-Glu-Val-...? & f $73-\ldots ?$ \\
\hline & 20 & 55 & $\mathrm{H}_{2} \mathrm{~N}-\mathrm{Thr}-\mathrm{Glu}$-Tyr-Gly-Leu-COOH & f $67-71$ \\
\hline & 21 & 56 & $\mathrm{H}_{2} \mathrm{~N}$-Ile-Asn-Asn-Lys-Ile-Trp-Cys-Lys-...? & f $74-\ldots ?$ \\
\hline \multirow[t]{7}{*}{ Cardosin B } & Band & $\begin{array}{l}\text { Molecular } \\
\text { mass } \\
(\mathrm{kDa})\end{array}$ & & \\
\hline & $\mathrm{A}$ & 8.0 & $\begin{array}{l}\mathrm{H}_{2} \mathrm{~N} \text {-Phe-Gln-Ile-Asn-Asn-Lys-Ile-Trp-Cys-Lys-Asp- } \\
\text { Asp-Gln-Asn-Pro-His-Ser-Ser-Asn-...? }\end{array}$ & f $72-\ldots ?$ \\
\hline & $\mathrm{B}$ & 7.2 & $\mathrm{H}_{2} \mathrm{~N}$-Gln-Ile-Asn-Asn-Lys-Ile-Trp-Cys-Lys-...? & f $73-\ldots ?$ \\
\hline & $\mathrm{C}$ & 6.5 & $\mathrm{H}_{2} \mathrm{~N}$-Gln-Ile-Asn-Asn-Lys-Ile-Trp-Cys-Lys-...? & f $73-\ldots ?$ \\
\hline & $\mathrm{D}$ & 6.0 & $\mathrm{H}_{2} \mathrm{~N}$-Glu-Gln-Leu-Thr-Lys-Cys-Glu-Val-Phe-Arg-...? & f $20-\ldots ?$ \\
\hline & $\mathrm{E}$ & 5.6 & $\begin{array}{l}\mathrm{H}_{2} \mathrm{~N} \text {-Glu-Gln-Leu-Thr-Lys-Cys-Glu-Val-Phe-Arg-Glu- } \\
\text { Leu-Lys-Asp-Leu-Lys-Gly-Tyr-Gly-...? }\end{array}$ & f $20-\ldots ?$ \\
\hline & $\mathrm{F}$ & 3.1 & $\mathrm{H}_{2} \mathrm{~N}$-Gln-Ile-Asn-Asn-Lys-Ile-Trp-Cys-Lys-...? & f $73-\ldots ?$ \\
\hline
\end{tabular}

Thr67, Leu71-Phe72, Phe72-Gln73, Gln73-Ile74, Ile78Trp79, Leu115-Asp116, and Leu124-Ala125. This finding suggests that, even though there are a few peptide bonds also acted upon by cardosin A (i.e., Phe28-Arg29, Ala59-Ile60, and Leu71-Phe72), cardosin B possesses a wider specificity than cardosin A. From Table 1, it can be seen that the band labeled as B (Figure 3b) and the peptide eluted at $\sim 56$ min (peak 21; Figure 5b) share the same $8 \mathrm{~N}$-terminal residues, which makes it likely that they correspond to the same peptide; the sequences of peptides labeled as C and D (Figure $3 \mathrm{~b}$ ) are similar to those associated with peaks 16 and 17 (Figure 5b). The sequence for band F (Figure $3 \mathrm{~b}$ ) is similar to that obtained for peak 19, eluted at 51 min (Figure 5b). Most bonds cleaved are also consistent with the findings of Faro (1991), who claimed that C. cardunculus proteinases possess endo- and exoproteinase activities, coupled with preference for peptide bonds involving apolar amino acids, especially (Phe-Leu-Ile)-X, where $\mathrm{X}$ is Val or Tyr. Other aspartic proteases (e.g., pepsin and hu- 

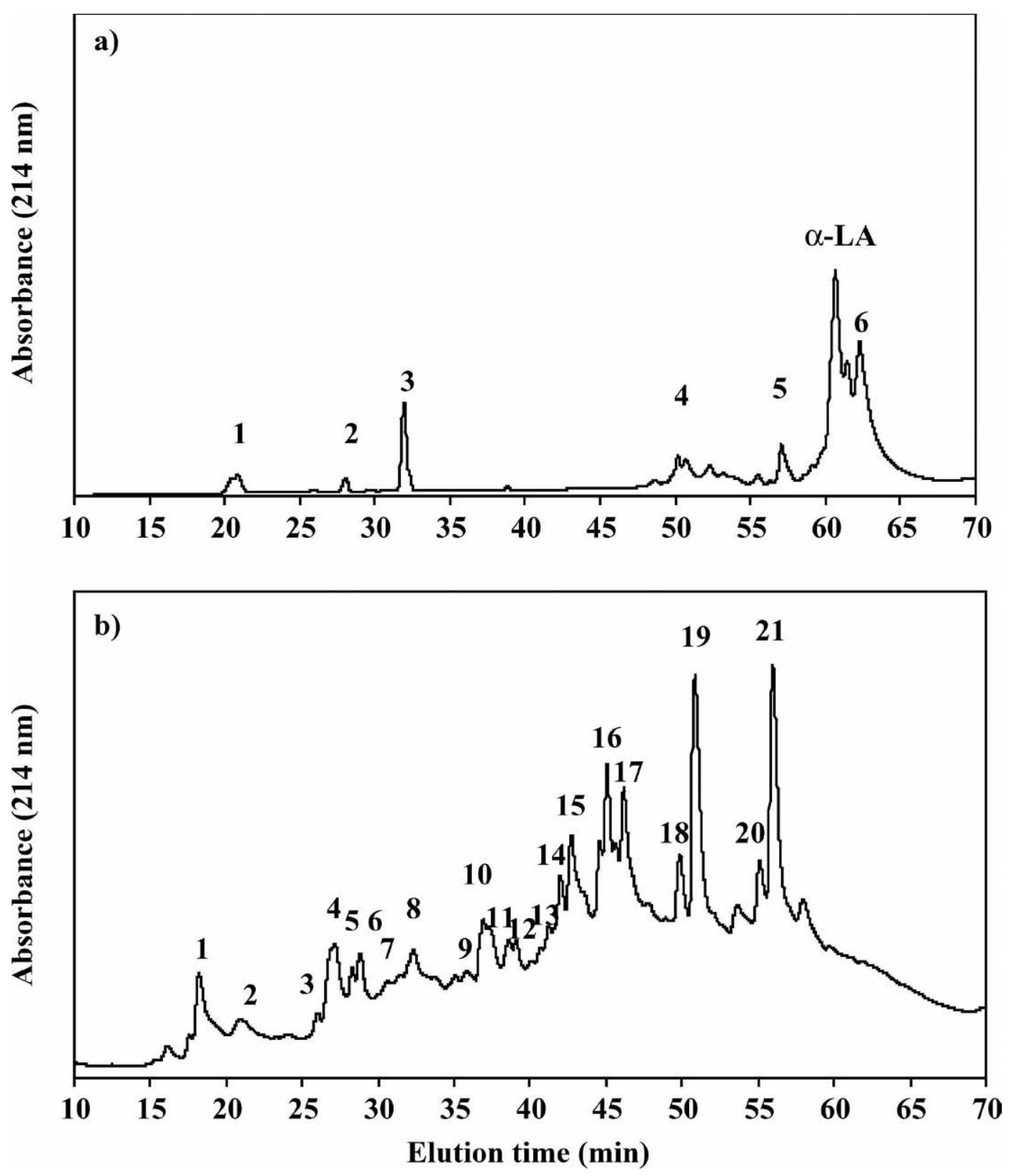

Figure 5. Elution profile by reverse phase-HPLC of hydrolyzates for the whole incubation time of $\alpha$-LA effected by a) cardosin A, and b) cardosin $\mathrm{B}$ at an enzyme to substrate ratio of $1 / 250$ (wt/wt), $55^{\circ} \mathrm{C}$, and $\mathrm{pH} 5.2$.

man cathepsin D) possess a comparable preference for hydrophobic residues (Guillou et al., 1991 ; Dunn and Hung, 2000; El-Zahar et al., 2005). Dalgalarrondo et al. (1995) showed that pepsin shows preferential hydrolysis toward Leu-X bonds in $\beta$-casein and $\beta$-LG. The proteolytic specificity of cardosins has been studied regarding other substrate proteins, including bovine, caprine, and ovine caseins. Those results are consistent with ours-cardosins show a similar ability either to cleave bonds between hydrophobic amino acid residues (such Phe-Tyr and Tyr-Leu) or involving mainly Phe, Trp, Tyr, Thr, and Leu residues (Faro et al., 1992; Macedo et al., 1996; Ramalho-Santos et al., 1996; Sousa and Malcata, 1998; Silva and Malcata, 2004). Furthermore, Silva and Malcata (2000) claimed that cardosin $\mathrm{B}$ acts more extensively on $\beta$-casein (with concomitant appearance of higher number of peptides) than cardosin $\mathrm{A}$, after $10 \mathrm{~h}$ of reaction.

Considering that the whey released in traditional cheese making (e.g., Serra da Estrela and Azeitão 
cheeses) contains most of the rennet initially added, in situ proteolysis brought about by rennet enzymes could be an interesting way to upgrade whey. Moreover, each cardosin acting upon $\alpha$-LA could contribute to the release of (functional) peptides from whey, or generate $\alpha$-LA-free product; in either case, the environmental problem caused by the high biochemical oxygen demand of whey would be alleviated, at least in part.

\section{CONCLUSIONS}

Significant differences exist between the activities and specificities of cardosins A and B toward the major whey proteins $-\alpha$-LA is high susceptible to hydrolysis brought about by either cardosin, whereas $\beta$-LG is not hydrolyzed to a significant extent. Cardosin B possesses broader specificity than cardosin A toward $\alpha$-LA, and the major cleavage sites are next to apolar and aromatic residues (e.g., Ala19-Glu20, Phe28-Arg29, Glu30Leu31, Tyr37-Gly38, Trp45-Val46, Phe50-His51, Ala59-Ile60, Ser66-Thr67, Leu71-Phe72, Phe72-Gln73, Gln73-Ile74, Ile78-Trp79, Leu115-Asp116, and Leu124Ala125). Five complete peptide sequences released from $\alpha$-LA were determined: f29-30, f29-37, f46-50, f6066, and f67-71. Conversely, cardosin A exhibits limited activity on $\alpha$-LA, and cleaves the peptide bonds Phe28Arg29, Ala59-Ile60, and Leu71-Phe72 (which were already found to be labile to cardosin $\mathrm{B}$ ); in addition, Gly54-Tyr55 and Leu105-Thr106 are cleaved. One complete (di)peptide sequence (f29-30) was also determined.

\section{ACKNOWLEDGMENTS}

Personal funding for R. M. Barros was via a Ph.D. fellowship (PRAXIS XXI BD/16037/98), by FCT (Portugal). Research expenses were partially covered by the research grant MILK FILM (POCI/CVT/60372/2004), also by FCT.

\section{REFERENCES}

Asselin, J., J. Herbert, and J. Amiot. 1989. Effect of in vitro proteolysis on the allergenicity of the major whey protein. J. Food Sci. 54:1037-1039.

Barros, R. M., C. Extermina, I. Gonçalves, B. Sousa, V. M. Balcão, and F. X. Malcata. 2003. Hydrolysis of $\alpha$-lactalbumin by cardosin A immobilized onto highly activated agarose-glutaraldehyde supports. Enzyme Microb. Technol. 33:908-916.

Barros, R., C. A. Ferreira, S. V. Silva, and F. X. Malcata. 2001. Quantitative studies on the enzymatic hydrolysis of milk proteins brought about by cardosins precipitated by ammonium sulfate. Enzyme Microb. Technol. 29:541-547.

Barros, R. M., and F. X. Malcata. 2002. Modelling the kinetics of whey protein hydrolysis brought about by enzymes from Cynara cardunculus. J. Agric. Food Chem. 50:4347-4356.

Barros, R. M., and F. X. Malcata. 2004. A kinetic model of whey protein hydrolysis brought about by a purified enzyme extracted from Cynara cardunculus. Food Chem. 88:351-359.
Bertrand-Harb, C., A. Baday, M. Dalgalarrondo, J.-M. Chobert, and T. Haertlé. 2002. Thermal modifications of structure and denaturation of $\alpha$-lactalbumin and $\beta$-lactoglobulin induce changes of solubility and susceptibility to proteases. Nahrung 46:283-289.

Campos, R., R. Guerra, M. Aguilar, O. Ventura, and L. Camacho. 1990. Chemical characterization of proteases extracted from wild thistle (Cynara cardunculus). Food Chem. 35:89-97.

Creamer, L. K., and A. K. H. MacGibbon. 1996. Some recent advances in the basic chemistry of milk proteins and lipids. Int. Dairy J. 6:539-568.

Dalgalarrondo, M., E. Dufour, J. M. Chobert, C. Bertrand-Harb, and T. Haertlé. 1995. Proteolysis of $\beta$-lactoglobulin and $\beta$-casein by pepsin in ethanolic media. Int. Dairy J. 5:1-14.

Dunn, B. M., and S.-H. Hung. 2000. The two sides of enzyme-substrate specificity: Lessons from the aspartic proteinases. Biochim. Biophys. Acta 1477:231-240.

El-Zahar, K., M. Sitohy, Y. Choiset, F. Métro, T. Haertle, and J. M. Chobert. 2005. Peptic hydrolysis of ovine $\beta$-lactoglobulin and $\alpha$ lactalbumin. Exceptional susceptibility of native ovine $\beta$-lactoglobulin to pepsinolysis. Int. Dairy J. 15:17-27.

Esteves, C. L., P. C. Veríssimo, C. J. Faro, and E. V. Pires. 1995. Biochemical characterization of the vegetable rennets from the flowers of cardoon: Comparison to calf rennet. J. Dairy Sci. 78(Suppl. 1):145. (Abstr.)

Faro, C. J. 1991. Purification and physico-chemical characterization of Cynara cardunculus L. protease. Ph.D. Dissertation, Universidade de Coimbra, Coimbra, Portugal.

Faro, C. J., A. J. G. Moir, and E. V. Pires. 1992. Specificity of a milkclotting enzyme extracted from the thistle Cynara cardunculus L.: Action on oxidised insulin and $\beta$-casein. Biotechnol. Lett. 14:841-846.

Guillou, H., G. Miranda, and J.-P. Pélissier. 1991. Hydrolysis of $\beta$ casein by gastric proteases. I. Comparison of proteolytic action of bovine chymosin and pepsin A. Int. J. Peptide Protein Res. 37:494-501.

Guo, M. R., P. F. Fox, and A. Flynn. 1995. Susceptibility of $\beta$-lactoglobulin and sodium caseinate to proteolysis by pepsin and trypsin. J. Dairy Sci. 78:2336-2344.

Heimgartner, U., M. Pietrzak, R. Geertsen, P. Bordelius, A. C. SilvaFigueiredo, and M. S. S. Pais. 1990. Purification and partial characterization of milk clotting proteases from flowers of Cynara cardunculus. Phytochemistry 29:1405-1410.

Kinekawa, Y. I., and N. Kitabatake. 1996. Purification of $\beta$-lactoglobulin from whey protein concentrate by pepsin treatment. J. Dairy Sci. 79:350-356.

Klemaszewski, J. L., and J. E. Klinsella. 1991. Sulfitolysis of whey proteins: Effects on emulsion properties. J. Agric. Food Chem. 39:1033-1036.

Kuwajima, K., M. Ikeguchi, T. Sugawara, Y. Hiraoka, and S. Sugai. 1990. Kinetics of disulfide bond reduction in $\alpha$-lactalbumin by dithiothreitol and molecular basis of superreactivity of the Cys6Cys120 disulfide bond. Biochemistry 29:8240-8249.

Lamas, E. M., R. M. Barros, V. M. Balcão, and F. X. Malcata. 2000. Hydrolysis of whey proteins by proteases extracted from Cynara cardunculus and immobilized onto highly activated supports. Enzyme Microb. Technol. 28:642-652.

Lowry, O. H., N. J. Rosenhough, A. L. Fan, and R. J. Randall. 1951. Protein measurement with the Folin phenol reagent. J. Biol. Chem. 193:265-275.

Maeda, A., K. Abe, M. Watanabe, and S. Arai. 1987. Peptic hydrolysis of bovine $\beta$-lactoglobulin to produce a low-phenylalanine peptide foodstuff for phenylketonuria. Agric. Biol. Chem. 51:1501-1507.

Macedo, I. Q., C. J. Faro, and E. V. Pires. 1996. Caseinolytic specificity of cardosin, an aspartic protease from the cardoon Cynara cardunculus L.: Action on bovine $\alpha_{\mathrm{s}^{-}}$and $\beta$-casein and comparison with chymosin. J. Agric. Food Chem. 44:42-47.

Miranda, G., and J.-P. Pélissier. 1983. Kinetic studies of in vivo digestion of bovine unheated skim-milk proteins in rat stomach. J. Dairy Res. 50:27-36.

Pellegrini, A., U. Thomas, N. Bramaz, P. Hunziker, and R. von Fellenberg. 1999. Isolation and identification of three bactericidal 
domains in the bovine $\alpha$-lactalbumin molecule. Biochim. Biophys. Acta 1426:439-448.

Pintado, M. E., and F. X. Malcata. 2000. Hydrolysis of ovine, caprine and bovine whey proteins by trypsin and pepsin. Bioprocess Eng. 23:275-282.

Pires, E. M. V. 1998. Cardosin A. Cardosin B. Pages 843-846 in Handbook of Proteolytic Enzymes. A. J. Barrett, N. D. Rawlings, and J. F. Woessner, ed. Academic Press, San Diego, CA.

Ramalho-Santos, M., J. Pissara, P. Veríssimo, S. Pereira, R. Salema, E. V. Pires, and C. J. Faro. 1997. Cardosin A, an abundant aspartic proteinase, accumulates in protein storage vacuoles in the stigmatic papillae of Cynara cardunculus L. Planta 203:204-212.

Ramalho-Santos, M., P. Veríssimo, C. J. Faro, and E. V. Pires. 1996. Action on bovine $\alpha_{\mathrm{s} 1}$-casein of cardosins $\mathrm{A}$ and $\mathrm{B}$, aspartic proteinases from the flowers of the cardoon Cynara cardunculus L. Biochim. Biophys. Acta 1297:83-89.

Reddy, M., K. N. Kella, and J. E. Kinsella. 1988. Structural and conformational basis of the resistance of $\beta$-lactoglobulin to peptic and chymotryptic digestion. J. Agric. Food Chem. 36:737-741.

Schmidt, D. G., R. J. Meijer, C. J. Slangen, and E. C. van Beresteijn. 1995. Raising the $\mathrm{pH}$ of the pepsin-catalysed hydrolysis of bovine whey proteins increases the antigenicity of the hydrolysates. Clin. Exp. Allergy 25:1007-1017.

Schmidt, D. G., and J. K. Poll. 1991. Enzymatic hydrolysis of whey proteins. Hydrolysis of $\alpha$-lactalbumin and $\beta$-lactoglobulin in buffer solutions by proteolytic enzymes. Neth. Milk Dairy J. 45:225-240.

Schmidt, D. G., and B. W. van Markwijk. 1993. Enzymatic hydrolysis of whey proteins. Influence of heat treatment of $\alpha$-lactalbumin and $\beta$-lactoglobulin on their proteolysis by pepsin and papain. Neth. Milk Dairy J. 47:15-22.

Silva, S. V., and F. X. Malcata. 2000. Comparative catalytic activity of two plant proteinases upon caprine caseins in solution. Food Chem. 71:207-214.

Silva, S. V., and F. X. Malcata. 2004. Influence of the coagulant level on early proteolysis in ovine cheese-like systems made with sterilized milk and Cynara cardunculus. J. Food Sci. 69:579-584.

Sitohy, M., J.-M. Chobert, and T. Haertlé. 2001. Peptic hydrolysis of methyl-, ethyl- and propyl-esters of $\beta$-caseins and $\alpha$-lactalbumin.1995. Milchwissenschaft 56:303-307.

Sousa, M. J., and F. X. Malcata. 1998. Identification of peptides from ovine milk cheese manufactured with animal rennet and extracts of Cynara cardunculus. Enzyme Microb. Technol. 22:305-314.

Stapelfeldt, H., P. H. Petersen, K. R. Kristiansen, K. B. Qvist, and L. H. Skibstes. 1996. Effect of high hydrostatic pressure on the enzymic hydrolysis of $\beta$-lactoglobulin B by trypsin, thermolysin and pepsin. J. Dairy Res. 63:111-118.

Tomarelli, R., M. Charney, and M. Harding. 1949. The use of azoalbumin as a substrate in the colorimetric determination of peptic and tryptic activity. J. Lab. Clin. Med. 34:428-433.

Veríssimo, P., C. L. Esteves, C. J. Faro, and E. V. Pires. 1995. The vegetable rennet of Cynara cardunculus L. contains two proteinases with chymosin and pepsin-like specificities. Biotechnol. Lett. $17: 621-626$

Veríssimo, P., C. J. Faro, A. J. Moir, Y. Lin, J. Tang, and E. V. Pires. 1996. Purification, characterization and partial amino acid sequencing of two new aspartic proteinases from fresh flowers of Cynara cardunculus L. Eur. J. Biochem. 235:762-768. 